\title{
Excess Supply of Nutrients, Fungal Community, and Plant Litter Decomposition: A Case Study of Avian-Derived Excreta Deposition in Conifer Plantations ${ }^{1}$
}

\author{
Takashi Osono \\ Center for Ecological Research, Kyoto University
}

Japan

\section{Introduction}

\subsection{Excess supply of nutrients and terrestrial ecosystems}

Human activities have greatly accelerated emissions of both carbon dioxide and biologically reactive nutrients such as nitrogen $(\mathrm{N})$ to the atmosphere (Canfield et al., 2010), which cause environmental changes affecting ecosystem processes and biodiversity in forests. Excess supply of $\mathrm{N}$ of anthropogenic origin to forest soils, such as combustion of fossil fuels, production of $\mathrm{N}$ fertilizers, and cultivation of $\mathrm{N}$-fixing legumes, is an example of such environmental changes often leading to a decrease of the rate of carbon dioxide evolution and decomposition (Fog, 1988; Berg and Matzner, 1997) and a concomitant increase in the amount of soil carbon stock (deVries et al., 2006; Zak et al., 2008). These changes are primarily attributable to the reduced activity of fungal ligninolytic enzymes that play crucial roles in the turnover of soil organic carbon and are known to be sensitive to $\mathrm{N}$ deposition (Sinsabaugh, 2010). However, such changes in the enzymatic activity are not consistently associated with changes in the abundance and diversity of fungi that are responsible for the activity (Waldrop and Zak, 2006; Blackwood et al., 2007; Hassett et al., 2009). This discrepancy merits further studies to examine the response of ecological and functional properties of fungal communities to excess supply of $\mathrm{N}$ and its consequences on the dynamics of carbon and $\mathrm{N}$ in forest soils.

The transfer of nutrients by waterbirds from aquatic to terrestrial ecosystems provides similar situations to the anthropogenic supply of nutrients because birds feed on fish in the aquatic zone and deposit their waste rich in nutrients to the terrestrial parts of their habitats. Such allochthonous input of $\mathrm{N}$ and other nutrients to terrestrial ecosystems can lead locally to substantial enrichment of soils and plants and alter food webs, nutrient cycling, and

\footnotetext{
1This manuscript should be cited as follows: Osono, T. (2011). Excess supply of nutrients, fungal community, and plant litter decomposition: a case study of avian-derived excreta deposition in conifer plantations, In: Environmental Change, S.S. Young and S.E. Silvern, (Ed.), 000-000, InTech, ISBN979-953307-109-0, Rijeka, Croatia
} 
ecosystem processes in bird colonies (Mizutani and Wada, 1988; Anderson and Polis, 1999). In contrast, much less concern has been directed toward the diversity and activity of saprobic fungi in forest soils affected by excess supply of avian-derived $\mathrm{N}$ and the consequences for carbon sequestration in forest soils.

\subsection{Cormorant populations in lakeside forests in Japan}

The great cormorant, Phalacrocorax carbo L., is a colonial piscivorous bird that is distributed almost all over the world (Johnsgard, 1993). In Japan, the cormorants breed and roost in trees in riparian woods and feed on fishes in lakes, rives, and coastal areas (Ishida et al., 2003). The population of cormorants increased rapidly after the 1980s as the number of new colonies increased (Kameda et al., 2003). For example, there were no breeding records of cormorants between World War II and 1982 within the watershed of Lake Biwa, currently one of the main habitats of cormorants in Japan, whereas the population size increased rapidly in the 1990s to reach more than 17,000 during the breeding season from January to August in 2003 (Kameda et al., 2006). The increased populations have caused serious conflicts with fisheries and forests in their habitats (Kameda et al., 2003).

Isaki Peninsula $\left(35^{\circ} 12^{\prime} \mathrm{N}, 136^{\circ} 5^{\prime} \mathrm{E}, 57 \mathrm{ha}\right)$, located on the southeast side of Lake Biwa (Fig. 1) and covered with plantations of Japanese cypress (Chamaecyparis obtusa Sieb. et Zucc.), was selected for the present study. The mean annual temperature is $15.1^{\circ} \mathrm{C}$ and annual precipitation is $1,474.5 \mathrm{~mm}$ at the Hikone Weather station about $20 \mathrm{~km}$ from the Isaki Peninsula. After cormorant nests were first discovered at Isaki Peninsula in 1988, the area of the colony expanded from 1.3 ha in 1992 to 19.3 ha in 1999 and the number of nests from 30 to 40 in 1989 to 5,300 in 1999 (Fig. 1) to become one of the major habitats of the cormorants in the watershed of Lake Biwa (Fujiwara and Takayanagi, 1999). Five study sites were chosen on Isaki Peninsula, Sites C, T, P, A, D, which had the same vegetation composition but were in different stages of breeding colony establishment (Table 1). A study plot $(50 \times 50 \mathrm{~m})$ was established at each site and used to study the effects of cormorant colonization on soils and vegetation.

\subsection{Responses of forest ecosystems to cormorant colonization}

During the breeding season, the input of bird excreta at Site P was estimated at 2.2 $\mathrm{t} / \mathrm{ha} /$ month (Kameda et al., 2000). Because the excreta are rich in $\mathrm{N}(11.1 \% \mathrm{w} / \mathrm{w}$ on average) and other nutrients such as $\mathrm{P}$ and $\mathrm{Ca}$, the excreta input was estimated to be the equivalent of $0.24 \mathrm{t} / \mathrm{ha} /$ month of excreta-derived $\mathrm{N}$, which corresponds to about 10,000 times the ordinary input by precipitation (Fig. 2) (Kameda et al., 2000). In addition, litterfall input at Site P during the breeding season was estimated at $2.6 \mathrm{t} / \mathrm{ha} / \mathrm{month}$, which was 7 to 22 times greater than that at Site C (Fig. 2) (Hobara et al., 2001). This increase of litterfall at Site $\mathrm{P}$ was due to damage of the overstory by the cormorants. Chamaecyparis obtusa was one of the most heavily damaged tree species at forest stands colonized by the cormorants (Ishida, 1996b). A part of forest stands intensively colonized by the cormorants declined due to high mortality of C. obtusa (Site D; Fig. 2) (Fujiwara and Takayanagi, 2001).

The forest decline was also partly and indirectly attributable to changes in soil properties caused by excess supply of excreta-derived nutrients. A dramatic increase in inorganic $\mathrm{N}$ pools, a decrease in carbon to $\mathrm{N}$ ratio, and an increase in nitrification rate were observed in forest floor materials and in soils at Sites P and A (Ishida, 1996a; Hobara et al., 2001), 
indicative of $\mathrm{N}$ saturation at the study sites exposed to bird colonization (Aber et al., 1998). Excreta-derived $\mathrm{N}$ was incorporated into not only soils but also aboveground tissues of plants, as indicated by natural ${ }^{15} \mathrm{~N}$ abundance as a natural tracer (Kameda et al., 2006). Because cormorants are piscivorous birds and one of the top predators in aquatic food webs, $\delta^{15} \mathrm{~N}$ of their tissues and excreta is markedly higher (i.e., 13 to $17 \%$ ) than those of $\mathrm{N}$ from precipitation and $\mathrm{N}$ fixation $(-1$ to $1 \%$ ). The data of $\delta 15 \mathrm{~N}$ in soils and plants were used to construct ' $\mathrm{N}$ stable isotope map' of Isaki Peninsula (Fig. 1) showing the spatial patterns of cormorant effects (Kameda et al., 2006).

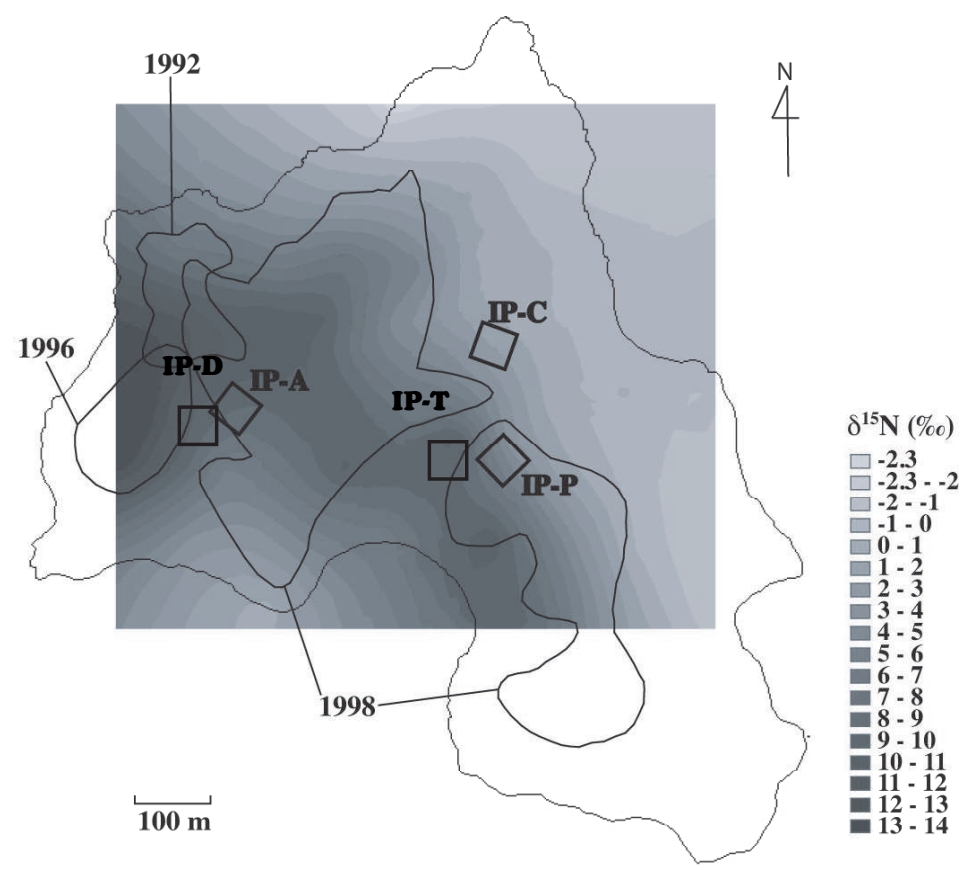

Fig. 1. Study sites, cormorant colony boundaries and the year of colony establishment, and nitrogen stable isotope map of Isaki Peninsula (IP) at Lake Biwa, Japan. The nitrogen stable isotope map shows the intensity and duration of cormorant colonization (Kameda et al., 2006). See Table 1 for the description of study sites.

\begin{tabular}{|c|c|c|}
\hline Site & Colonization & Description \\
\hline $\mathrm{C}$ & No colonization & Never colonized by cormorants (control) \\
\hline $\mathrm{T}$ & Spring 1999 & $\begin{array}{l}\text { Temporarily colonized for } 3 \text { months before cormorants were } \\
\text { expelled by hunters; no cormorants thereafter }\end{array}$ \\
\hline $\mathrm{P}$ & 1997-2003 & Presently colonized; cormorants abundant \\
\hline A & 1996-1999 & Abandoned after 3 years of colonization; no cormorants \\
\hline $\mathrm{D}$ & 1992-1996 & Declined after 4 years of intensive colonization; no cormorants \\
\hline
\end{tabular}

Table 1. Study sites and descriptions of breeding colony of cormorants at Isaki Peninsula. 


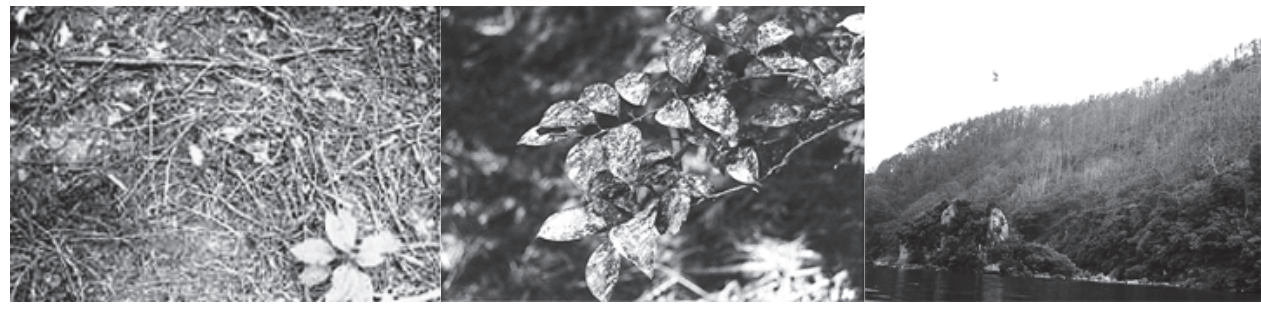

Fig. 2. Surface of the forest floor covered with dead twigs fallen at Site A (left), leaves of understory vegetation covered with excreta deposited at Site P (middle), and dead trees of Chamaecyparis obtusa in a declined forest stand at Site D (right).

\subsection{Purposes}

In this chapter I summarize a series of published papers reporting the effects of excess supply of $\mathrm{N}$ as avian excreta on fungal communities and plant litter decomposition in conifer plantations colonized by cormorants (Osono et al., 2002, 2006a, 2006b, unpublished data; Katsumata, 2004) to present a comprehensive picture of their relationships and to predict long-term patterns in the accumulation of dead plant tissues and excreta-derived nutrients on the forest floor. The following hypotheses are addressed. (i) The excess supply of nutrients affected the abundance, diversity, and species composition of saprobic fungal communities, as well as their nutrition and activity (Sections 2, 3, and 4). (ii) Such changes in fungal diversity and activity in turn affected the decomposition processes of dead plant tissues, such as needles, twigs, and stems (Section 5). (iii) Dead plant tissues abundantly supplied to the forest floor serve as reservoirs of excreta-derived $\mathrm{N}$ (Section 6). The studies explicitly demonstrate that the changes in fungal communities and decomposition of dead plant tissues had consequences regarding the long-term patterns of accumulation of carbon and $\mathrm{N}$ in soils of forest stands colonized by cormorants.

\section{Excreta deposition and fungal communities}

It is usually difficult to study both the biomass and the species composition of fungal assemblages simultaneously with any single method (Osono, 2007). Thus, fungal biomass and species composition were studied separately. Firstly, dead needles and twigs of $C$. obtusa were collected from the forest floor, and the length of hyphae in the tissues was examined with a direct observation method as a measure of fungal biomass and compared among forest stands with different histories of cormorant colonization (Osono et al., 2002). Twigs were defined as woody tissues with a diameter less than $0.5 \mathrm{~cm}$.

\subsection{Fungal biomass in dead needles and twigs}

The total hyphal length was generally longer in needles than in twigs and was in the order: Sites C > P > A (Fig. 3), suggesting that the biomass of fungi was reduced in forest stands supplemented with excreta. The length of clamp-bearing hyphae, belonging to the Basidiomycota (Fig. 4), accounted for 10 to $11 \%$ of the total hyphal length at Site C but was reduced markedly at Sites $\mathrm{P}$ and A (Fig. 3).

The reduced fungal biomass at Sites $\mathrm{P}$ and $\mathrm{A}$ was possibly attributable to the inhibitory effects on fungal growth of excreta rich in ammonia, uric acid, and salts (see Section 4.1) and 
to the decreased availability of carbon compounds owing to condensation of N-rich compounds (Osono et al., 2002). Söderström et al. (1983) also reported a decrease in microbial biomass after $\mathrm{N}$ fertilization in coniferous forest soils. The lower length of clampbearing hyphae (i.e., biomass of basidiomycetous fungi) at Sites P and A than at Site C might also have been due to a biochemical suppression of lignin-degrading enzymes of some fungi in the Basidiomycota caused by excess excreta deposition (Keyser et al., 1978; Fenn et al., 1981). This may have reduced competitiveness relative to that of other non-ligninolytic fungi and hence hyphal growth of basidiomycetes at Sites P and A.
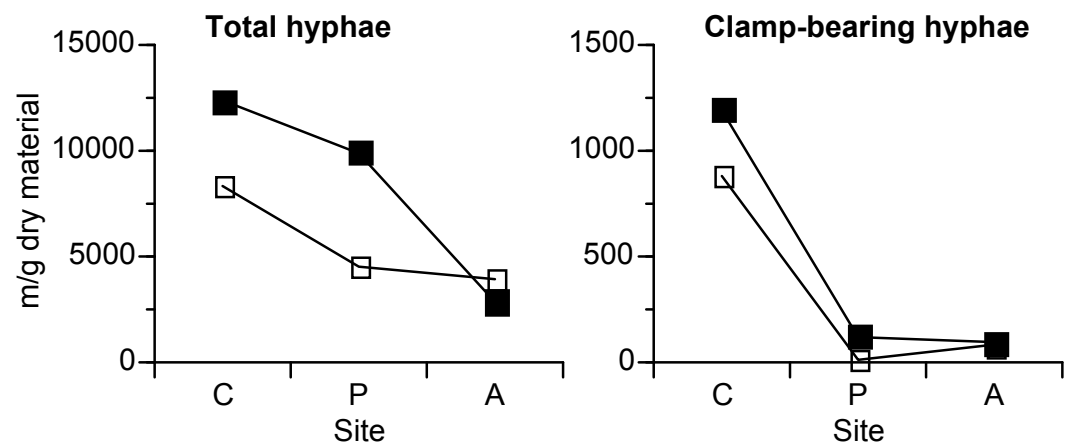

Fig. 3. Total hyphal lengths and lengths of clamp-bearing hyphae in dead needles and twigs of Chamaecyparis obtusa examined with an agar film method. needles; $\square$ twigs. Sites are as in Table 1. Data after Osono et al. (2002).

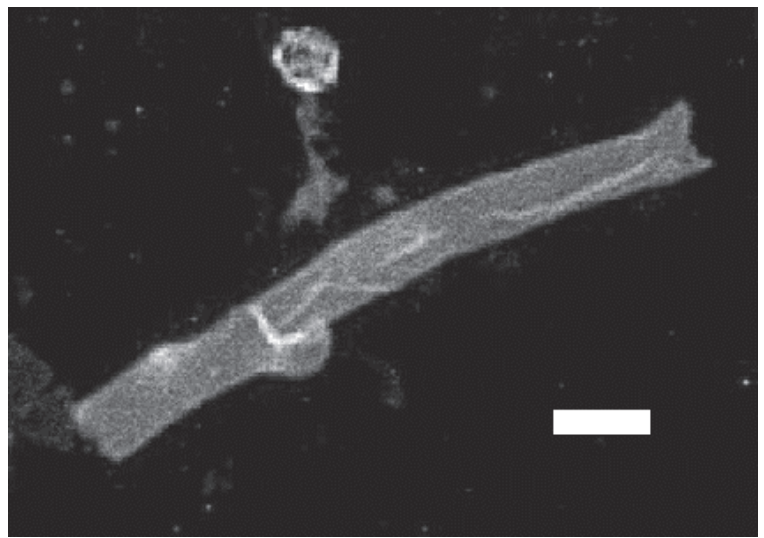

Fig. 4. A hypha with a clamp connection (arrow) observed under a microscope. Bar $=5 \mu \mathrm{m}$.

\subsection{Diversity and species composition of fungi}

Secondly, species richness, diversity, and equitability of fungal assemblages associated with the dead needles and twigs were examined with a culture-dependent, surface disinfection method (Fig. 5). A total of 231 isolates of 70 fungal species were isolated from dead needles and twigs at Sites C, P, and A. Species richness (i.e., the number of species isolated) in needles was higher at Site $\mathrm{A}$ than at Sites $\mathrm{C}$ and $\mathrm{P}$, but the species richness in twigs was 
similar among the sites. Diversity index was higher in twigs than in needles and was higher at Site A than at Sites $C$ and P. Equitability was higher in twigs than in needles and in the order: Sites $\mathrm{A}>\mathrm{P}>\mathrm{C}$ in both needles and twigs.
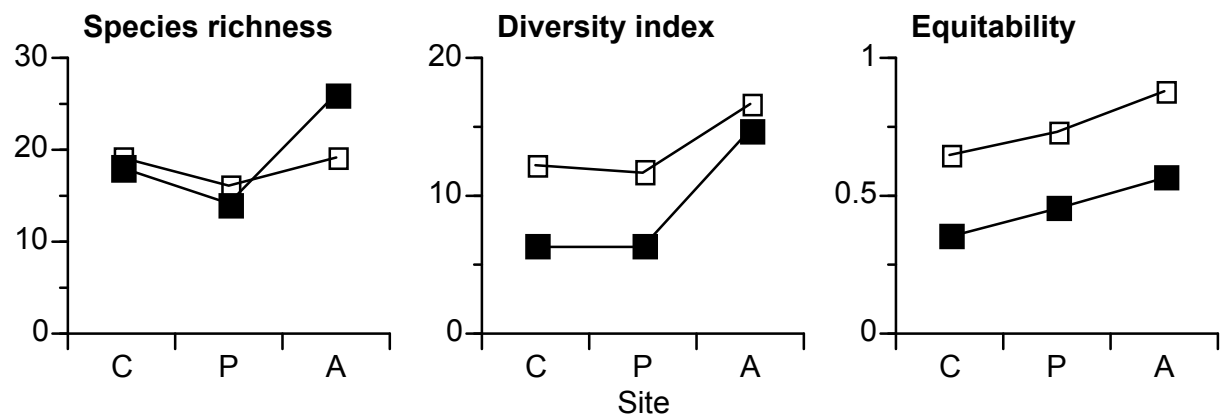

Fig. 5. Diversity of fungal assemblages in dead needles and twigs of Chamaecyparis obtusa. needles; $\square$ twigs. Sites are as in Table 1. Species richness (S) equals to the total number of species. Simpson's diversity index (D) and equitability (E) were calculated as: $\mathrm{D}=1 / \sum \mathrm{P} i^{2}$, $\mathrm{E}=\mathrm{D} / \mathrm{S}$, where $\mathrm{P} i$ was the relative frequency of the $i$ th species in each fungal assemblage (Osono et al., 2002).
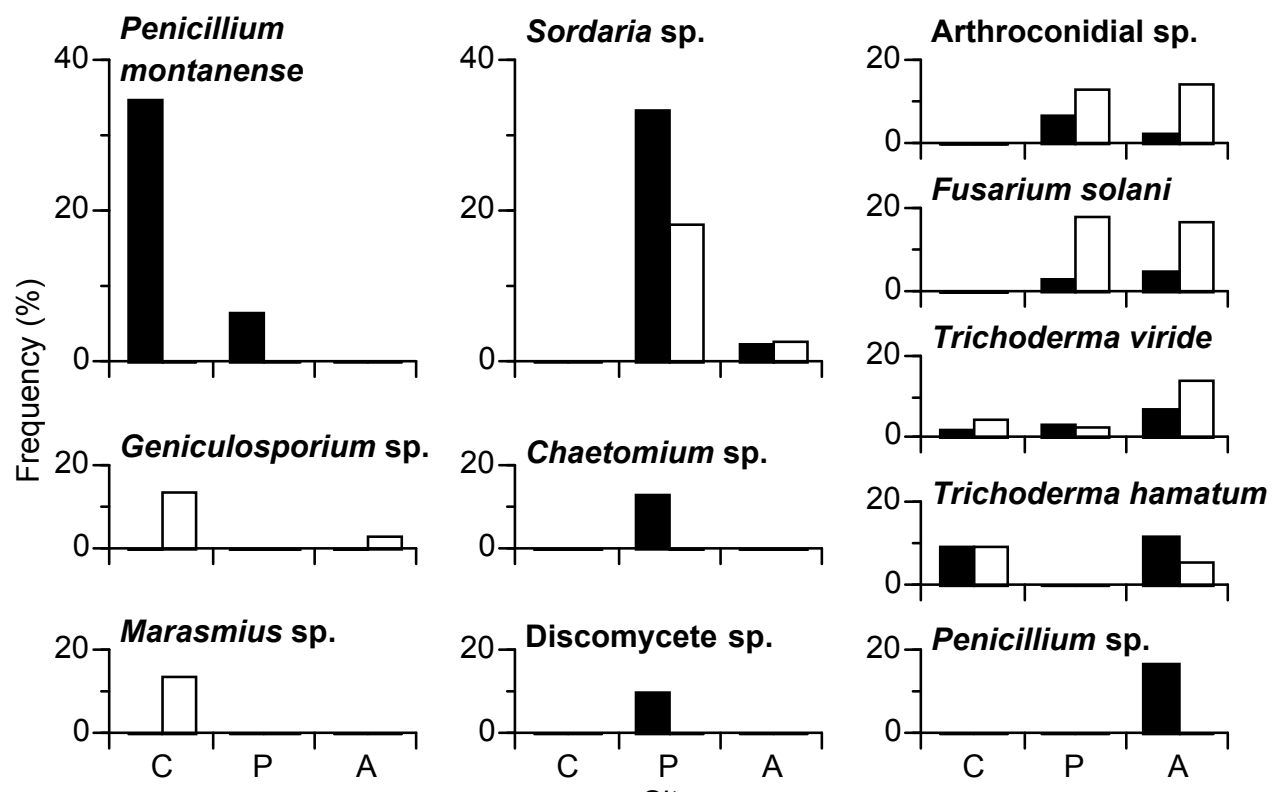

Fig. 6. Relative frequency (\%) of major fungal species in dead needles and twigs of Chamaecyparis obtusa (Osono et al., 2002). Black bar, needles; open bar, twigs. Sites are as in Table 1. 
A few studies have examined the effects of bird colonization on soil fungal assemblages. Ninomiya et al. (1993) and Schoenlein-Crusius et al. (1996) observed no difference in fungal diversity between soil affected by the presence of birds and control soil, which contrasted with the results of the present study. Osono et al. (2002) summarized previous studies on the effects of ornithologenic and anthropogenic eutrophication on the diversity of soil saprobic fungal assemblages and found that the response was variable depending on the study. The inconsistency of the eutrophication effect on fungal diversity suggests that factors other than nutrient addition may also affect the diversity, such as the amount and/or form of nutrients added, time after fertilization, physical and chemical properties of soils, and different methodologies used for fungal isolation.

Clear differences were found for the patterns of occurrence of 11 major fungal species among the sites (Fig. 6). Penicillium montanense, Geniculosporium sp., and Marasmius sp. dominated at Site C were decreased at Sites P and A. Koide and Osono (2003) reported a similar result that an udentified species of Geniculosporium was isolated from leaf litter of Camellia japonica at Site C but not at Site A. This contrasted to Sordaria sp., Chaetomium sp., Discomycete sp., an unidentified arthroconidial species, and Fusarium solani, which showed marked increases at Site P in both needles and twigs. Arthroconidial sp. and F. solani also occurred frequently at Site A, as did Trichoderma viride, T. hamatum, and Penicillium sp. The absence of a ligninolytic basidiomycete Marasmius sp. from twigs at Sites P and A was consistent with the decrease in clamp-bearing hyphae (Fig. 3) and may have been due to enzymatic suppression by excessive inorganic-N or N-rich compounds in these sites as discussed above. Sordaria sp. is considered to be a coprophilous species associated with bird excreta.

In summary, the abundance of basidiomycetes (Fig. 3) and the relative frequency of ligninolytic Marasmius sp. (Fig. 6) were reduced at presently colonized (Site P) and abandoned forest stands (Site A), possibly due to excess supply of nutrients in excreta, such as N. To verify this possibility, effects of excreta addition on fungal growth and decomposition was examined under pure culture conditions in Section 4.

\section{Utilization of excreta-derived nutrients by fungi}

Utilization of cormorant-derived $\mathrm{N}$ by fungi was demonstrated by investigating the natural ${ }^{15} \mathrm{~N}$ abundance in fruit bodies of litter- and wood-decomposing fungi collected in the study sites. ${ }^{15} \mathrm{~N}$ enrichments in plant tissues, forest floor materials, and mineral soils due to excreta deposition were demonstrated in the cormorant colonies at Isaki Peninsula (Section 1.3; Fig. 1), which was associated with such processes as trophic enrichment through aquatic food webs and ammonia volatilization from soils (Kameda et al., 2006). Using natural ${ }^{15} \mathrm{~N}$ abundance as a natural tracer thus makes it possible to test whether fungi utilized excretaderived $\mathrm{N}$ in the colonized forests.

The ${ }^{15} \mathrm{~N}$ values of fruiting bodies at Site $\mathrm{C}$ were 0.1 to $1.5 \%$ on average and at similar levels to that in precipitation at the vicinity of the study sites (Fig. 7) and were within the range for saprobic fungi previously reported (e.g., Kohzu et al., 1999; Trudell et al., 2004). $\delta^{15} \mathrm{~N}$ was significantly (generalized linear model, $\chi^{2}=39.0, \mathrm{P}<0.001$ ) different among Sites $\mathrm{C}, \mathrm{P}$, and A and was significantly $\left(\chi^{2}=15.4, \mathrm{P}<0.001\right)$ higher in litter- than in wood-decomposing fungi (Fig. 7). Mean $\delta^{15} \mathrm{~N}$ values of fruiting bodies were in the order: Sites $\mathrm{A}>\mathrm{P}>\mathrm{C}$ for both litterand wood-decomposing fungi (Fig. 7). $\delta^{15} \mathrm{~N}$ of dead needles, forest floor materials, and woody debris were also higher at Sites $\mathrm{P}$ and $\mathrm{A}$ than at Site $\mathrm{C}$, and fruiting bodies of fungi 
were generally enriched in ${ }^{15} \mathrm{~N}$ relative to their substrata collected at the same sites. Fruiting bodies of litter-decomposing fungi at Sites $\mathrm{P}$ and $\mathrm{A}$ and those of wood-decomposing fungi at Site A had similar or higher $\delta^{15} \mathrm{~N}$ values than that in excreta (Fig. 7).

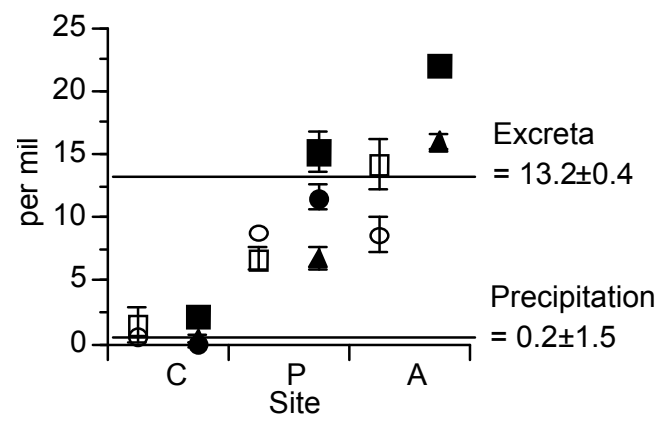

Fig. 7. Nitrogen stable isotope ratios of fruiting bodies of litter- ( ) and wood-decomposing fungi $(\square)$ (T. Osono, unpublished). Nitrogen stable isotope ratios of substrates for fungi are also shown: $\ell$ dead needles of Chamaecyparis obtusa; forest floor materials; $\bigcirc$ woody debris. Values indicate means \pm standard errors. Sites are as in Table 1. Horizontal lines indicate $\delta^{15} \mathrm{~N}$ values for excreta (means \pm standard errors, $\left.\mathrm{n}=12\right)$ and for precipitation $(\mathrm{n}=5)$ (Kameda et al., 2006). A total of 44 samples of fungal fruiting bodies representing 24 taxa were qualitatively collected from February 2000 to April 2003 and used for the analysis.

These results showed the effects of ${ }^{15} \mathrm{~N}$-enriched excreta deposition on fruiting bodies of litter- and wood-decomposing fungi at the forest stands colonized by the cormorants. Previous studies have been successful in using $\mathrm{N}$ stable isotope ratios to demonstrate the transfer of animal-derived $\mathrm{N}$ to biotic components in terrestrial ecosystems, such as seabird rookeries (Mizutani and Wada, 1988; Wainright et al., 1998) and bear habitats where salmons are transferred from coastal waters to riparian forests (Wilkinson et al., 2005; Nagasaka et al., 2006). The uptake of excreta-derived $\mathrm{N}$ can alter metabolic activity of fungal mycelia, which is investigated in the next section.

\section{Reduction of fungal growth and decomposition by excreta}

The results of Sections 2 and 3 suggest possible effects of excreta on fungal growth and decomposition of plant tissues. These effects were verified with pure culture tests of fungal growth and decomposition on an agar medium supplemented with excreta in comparison with those on a control medium without excreta (Osono et al., 2006b).

In September 2000, water collectors with 15-cm diameter funnels on the top were installed on the forest floor within each of Sites $\mathrm{C}$ and $\mathrm{P}$ to collect throughfall (i.e., excess water shed from wet leaves onto the ground surface). The water samples from Site $C$ contained throughfall (rainfall plus leaf leachates), whereas that from Site P contained the throughfall plus excreta of the cormorants. The water sample from Site $\mathrm{P}$ had higher $\mathrm{pH}$ and electrical conductivity and higher contents of total carbon, total $\mathrm{N}$, and $\mathrm{NH}_{4}-\mathrm{N}$ than that from Site $\mathrm{C}$ (Osono et al., 2006b). Throughfall from Sites C and P was mixed with $2 \%$ agar (w/v) and sterilized to prepare agar media that were denoted here as media $\mathrm{C}$ and $\mathrm{P}$, respectively. 


\subsection{Excreta addition reduced fungal growth}

Linear growth rates of 22 fungal isolates (12 basidiomycetes, 11 ascomycetes, and 1 zygomycete) were compared between media C and P. Nineteen of the 22 isolates were collected in the study sites, and another three isolates in the Basidiomycota were obtained from a culture collection. The mean value of linear growth rates on medium $\mathrm{P}$ was significantly lower than that on medium C (Fig. 8), indicating that excreta of the cormorants generally suppressed the mycelial extension of fungi. When taxonomic groups of fungi were examined separately, the linear growth rates for the Basidiomycota were significantly (paired t-test, $\mathrm{n}=12, \mathrm{P}<0.05$ ) lower on medium $\mathrm{P}$ than on medium $\mathrm{C}$, whereas the difference was not significant for the Ascomycota (paired t-test, $n=11, P>0.05$ ). These results are consistent with the field measurements showing that hyphal lengths in needle and twigs were shorter at Site $\mathrm{P}$, where the forest floor suffered excreta deposition, than at Site $\mathrm{C}$ and that the reduction was obvious for clamp-bearing hyphae that belong to the Basidiomycota (Fig. 3). Possible inhibitory factors responsible for the decrease of fungal growth include the toxicity of ammonia and uric acid and the higher $\mathrm{pH}$ and salt concentration in excreta, as discussed above.

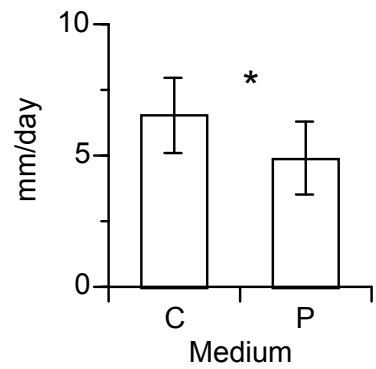

Fig. 8. Linear growth rate of fungal colony on media $\mathrm{C}$ and $\mathrm{P}$ at $20^{\circ} \mathrm{C}$ under pure culture conditions. Medium P contained excreta. The original data are in Osono et al. (2006b).

Values indicate means \pm standard errors for 22 fungal species tested. Results of paired t-tests are shown. ${ }^{*} \mathrm{P}<0.05$.

\subsection{Excreta addition retarded fungal decomposition of needles}

Another pure culture decomposition test was carried out for 13 (eight basidiomycetes and five ascomycetes) of the 22 fungal isolates to evaluate the effect of excreta addition on decomposition (Osono et al., 2006b). Dead needles of C. obtusa collected at Site C were used as a substratum. The mean value of mass loss of needles on medium $\mathrm{P}$ was significantly lower than that on medium C (Fig. 9), indicating that excreta of the cormorants generally reduced the fungal decomposition. This reduction in decomposition was due to the suppression of decomposition of acid-unhydrolyzable residue (AUR) in needles, as the mass loss of AUR was significantly lower on medium P than on medium C (Fig. 9). In contrast, the mass loss of total carbohydrates was not significantly different between the media $\mathrm{C}$ and $\mathrm{P}$ (Fig. 9). The mass loss of $\mathrm{N}$ was significantly lower on medium $\mathrm{P}$ than on medium $\mathrm{C}$ (Fig. 9), indicating more accumulation of $\mathrm{N}$ in needles when fungi were incubated on medium $\mathrm{P}$. $\delta^{15} \mathrm{~N}$ of needles decomposed by fungi on medium $\mathrm{P}(1.21 \pm 0.15 \%$, mean \pm standard error, $\mathrm{n}=13$ ) was significantly (paired t-test, $\mathrm{P}<0.001, \mathrm{n}=13$ ) higher than that on medium $\mathrm{C}$ 
$(0.51 \pm 0.06 \%$ o $)$, suggesting that $\mathrm{N}$ in excreta was translocated into needles during the fungal decomposition on medium $P$.

When taxonomic groups of fungi were examined separately, the mean values of mass loss of AUR were significantly lower on medium $\mathrm{P}$ than on medium $\mathrm{C}$ for the Basidiomycota (paired t-test, $\mathrm{n}=8, \mathrm{P}<0.05$ ), whereas the difference was not significant for the Ascomycota (paired t-test, $\mathrm{n}=5, \mathrm{P}>0.05$ ), suggesting that AUR decomposition by basidiomycetes is more sensitive to excreta than that by ascomycetes. The AUR fraction, which has been commonly denoted as Klason lignin, contains lignin, tannin, and cutin (Preston et al., 1997) as well as humic substances produced secondarily during fungal decomposition (Fukasawa et al., 2009). The AUR fraction thus represents recalcitrant components in plant tissues and often limits decomposition and nutrient dynamics (Osono and Takeda, 2004). Because a high concentration of inorganic $\mathrm{N}$ can cause biochemical suppression of lignin-degrading enzymes responsible for AUR decomposition (Keyser et al., 1978; Fenn et al., 1981; Osono and Takeda, 2001), excreta rich in $\mathrm{N}$ are probably responsible for the observed sensitivity of ligninolytic basidiomycetes to excreta on medium $\mathrm{P}$.
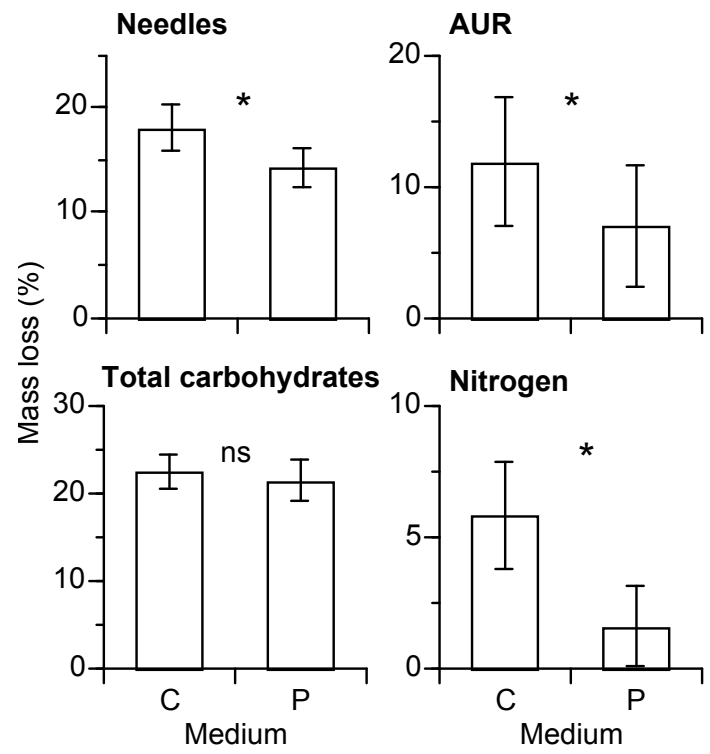

Fig. 9. Mass loss (\% original mass) of dead needles of Chamaecyparis obtusa and of acidunhydrolyzable residue (AUR), total carbohydrates, and nitrogen in the needles on medium $\mathrm{C}$ and P. Medium P contained excreta. The original data are in Osono et al. (2006b). The needles were sterilized with ethylene oxide gas, inoculated with fungal isolates, and incubated at $20^{\circ} \mathrm{C}$ for 12 weeks in the dark. Values indicate means \pm standard errors for 13 fungal species tested. Results of paired t-tests are shown. ${ }^{*} \mathrm{P}<0.05$, ns non significant.

In summary, the pure culture tests demonstrated that cormorant excreta negatively affected fungal growth and decomposition of needles and that ligninolytic basidiomycetes are more sensitive to excreta than ascomycetes. The reduced growth and decomposition by ligninolytic basidiomycetes due to excreta can alter the decomposition processes of dead 
plant tissues in the field, because these fungi are primary agents removing recalcitrant compounds from the tissues and mobilizing nutrients (Osono, 2007). Consequently, it is hypothesized that the reduction in biomass (Fig. 3) and activity (Figs. 8 and 9) of ligninolytic basidiomycetes due to excreta addition would result in the reduction of long-term decomposition rates, the accumulation of recalcitrant compounds in decomposing plant tissues, and the concomitant immobilization of nutrients in the tissues. These hypotheses are examined in detail in the next section.

\section{Excreta deposition and decomposition of dead plant tissues in the field}

A litterbag experiment (Fig. 10) was performed to follow the two-year decomposition of needles and twigs of $C$. obtusa on the forest floor and to compare them between Sites $C$ and $\mathrm{P}$ to estimate the possible effects of excreta on the decomposition (Osono et al., 2006a). In another field survey, mass and $\mathrm{N}$ content of coarse woody debris (CWD: logs, snags, and stumps with diameter equal to or greater than $10 \mathrm{~cm}$ ) were examined in the study sites to estimate the decomposition processes in cormorant-colonized forests.

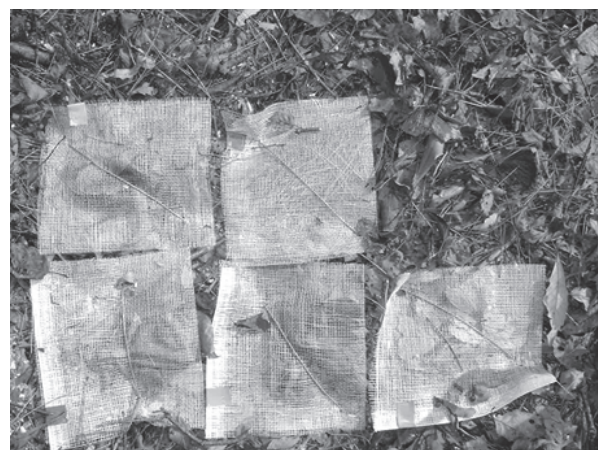

Fig. 10. Litterbags to study long-term decomposition of dead plant tissues in the field. In the study of Osono et al. (2006a), needles and twigs collected at Site $C$ were enclosed in polypropylene shade cloth $(10 \times 10 \mathrm{~cm}$, mesh size of approx. $2 \mathrm{~mm})$ and incubated on the forest floor at Sites $\mathrm{C}$ and $\mathrm{P}$ for two years. The litterbags were retrieved at 3- (the first year) or 6-month (the second year) intervals to analyze remaining mass and contents of organic chemical constituents and nutrients.

\subsection{Rate of mass loss of needles and twigs and recalcitrant compounds}

Over the two-year period, the mass loss was slower at Site P than at Site C and faster in needles than in twigs (Fig. 11). AUR mass loss in needles and twigs showed similar trends to mass loss of whole tissues and was slower at Site P than at Site C (Fig. 11). In contrast, mass loss of total carbohydrates in needles and twigs showed similar patterns between Sites $\mathrm{C}$ and P (data not shown; Osono et al., 2006a). These results support the hypotheses that the excreta deposition can lead to a reduction in decomposition rates and the accumulation of recalcitrant compounds in the decomposing plant tissues. The reduced AUR decomposition at Site $\mathrm{P}$ was primarily attributable to the reduced biomass and activity of ligninolytic basidiomycetes due to excess supply of excreta-derived N, as discussed above. 


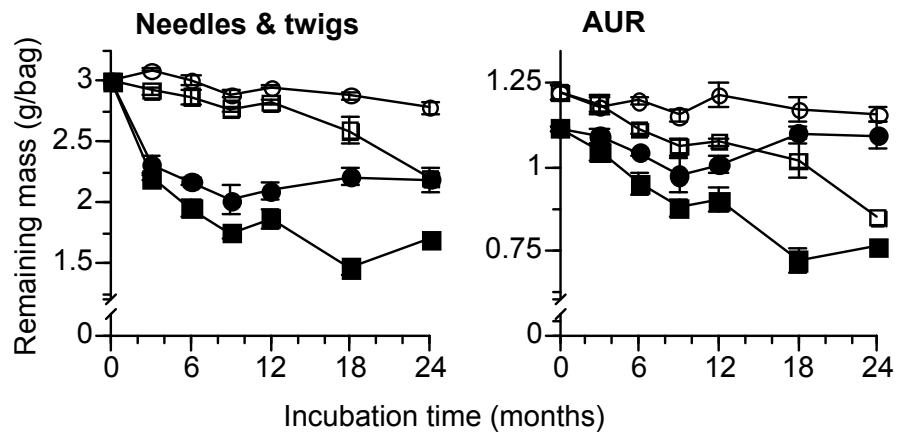

Fig. 11. Changes in remaining mass of needles and twigs of Chamaecyparis obtusa (left) and of acid-unhydrolyzable residue (AUR) in needles and twigs (right) at Sites $\mathrm{C}$ and $\mathrm{P}$ examined for two years in the field (Osono et al., 2006a). needles at Site C; needles at Site P; twigs at Site $\mathrm{C} ; \bigcirc$ twigs at Site P. Sites are as in Table 1 . Values indicate means \pm standard errors $(n=3)$.

\subsection{Immobilization of excreta-derived nitrogen}

The mass of $\mathrm{N}$ in needles at Site $\mathrm{P}$ increased rapidly during the first 3 months and was relatively constant thereafter, whereas that at Site $\mathrm{C}$ decreased during decomposition (Fig. 12). The mass of $\mathrm{N}$ in twigs also increased at Site $\mathrm{P}$, whereas such an increase was not detected at Site C (Fig. 12). The net increase, i.e. net immobilization, of $\mathrm{N}$ at Site P indicates the incorporation of external $\mathrm{N}$ into decomposing plant tissues. $\delta^{15} \mathrm{~N}$ values of the plant tissues at Site $\mathrm{P}$ increased rapidly during the first 3 months to reach the value of cormorant's excreta (13.2 $\pm 0.4 \%$, mean \pm standard error, $n=12$; Kameda et al., 2006), whereas such an increase was not detected at Site C (Fig. 12). This stable isotope tracer successfully demonstrated that this exogenous $\mathrm{N}$ incorporated into the decomposing plant tissues was derived from excreta.

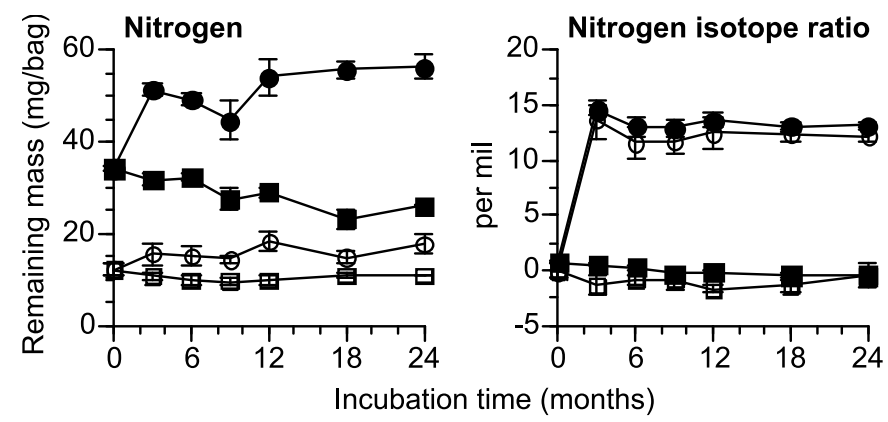

Fig. 12. Changes in remaining mass of nitrogen and nitrogen stable isotope ratio $\left(\delta^{15} \mathrm{~N}, \%\right.$ o $)$ in needles and twigs of Chamaecyparis obtusa at Sites C and P in the field (Osono et al. 2006a). Symbols are as in Fig. 11. Values indicate means \pm standard errors $(n=3)$.

Causal relationships can be expected among the increased $\mathrm{N}$ immobilization, the AUR accumulation, and the reduced mass loss of whole tissues. The secondary formation of nitrogenous recalcitrant substances can be stimulated during plant litter decomposition 
under N-rich conditions (Berg, 1986, 1988). The $\delta^{15} \mathrm{~N}$ values (10.5 to $12.3 \%$ ) of AUR in needles and twigs at Site P, compared to those at Site C (-1.0 to 1.1\%o), clearly indicated that excreta-derived $\mathrm{N}$ was incorporated into AUR during decomposition (Osono et al., 2006a). The formation of nitrogenous recalcitrant compounds registered as AUR resulted in the reduced net loss of mass of AUR, which in turn retarded the loss of mass of whole tissues.

\subsection{Decomposition of coarse woody debris}

Coarse woody debris (CWD) serves as a major pool and source of carbon and nutrients in forest ecosystems because of its long turnover time (Harmon et al., 1986). In Isaki peninsula, the mass of CWD ranged from 15.5 to $42.0 \mathrm{t} / \mathrm{ha}$ at Sites $\mathrm{P}, \mathrm{A}$, and D (Fig. 13). These values were 2 to 5.5 times that at Site C (7.7 t/ha, Fig. 13) and generally larger than CWD mass in most undisturbed coniferous forests (Harmon et al., 1986). The greater CWD mass in the colonized forests was due to the increased mortality of stems as snags in the colonized forest stands (Fujiwara and Takayanagi, 2001; see Section 1.3) which accounted for 68 to $87 \%$ of total CWD mass at Sites P, A, and D (Fig. 13). Most snags persisted as standing-dead for 10 years after the bird colonization at Site D, but gradually shifted from decay class I to II during the period (Fig. 13).

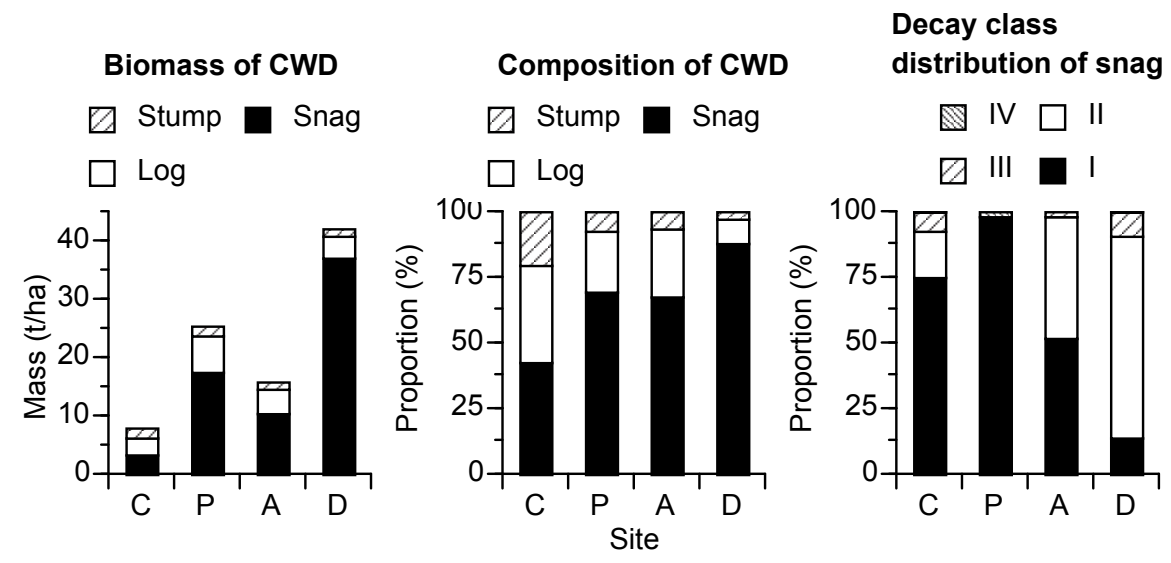

Fig. 13. Mass and composition of coarse woody debris (CWD) and decay class distribution of snags at Sites C, P, A, and D at Isaki Peninsula (Katsumata, 2004). Sites are as in Table 1. CWD (diameter equal to or greater than $10 \mathrm{~cm}$ ) were investigated in belt transects $(4 \mathrm{~m}$ width, a total length of 2,030 m, 0.07 to 0.30 ha for each site) in 2003. CWD were recorded for each of three categories (log, snag, stump) and each of five decay classes [decay class I (recently dead and minimally decomposed) to $\mathrm{V}$ (strongly decomposed)] according to visual criteria for coniferous CWD (Sollins, 1982). No snag was classified into decay class V in the study of Katsumata (2004).

The nitrogen content of CWD of C. obtusa was generally low regardless of the category (log, snag, or stump) and the decay class (I to V), mostly ranging from 0.8 to $1.5 \mathrm{mg} / \mathrm{g}$ (Fig. 14). The exceptions were logs in decay class IV at Sites $\mathrm{P}$ and $\mathrm{A}$ that had higher $\mathrm{N}$ content (mean values of 6.6 and $5.8 \mathrm{mg} / \mathrm{g}$, respectively) (Fig. 14). However, the differences in N contents in CWD among the categories or the decay classes were not statistically significant (generalized linear model, $\mathrm{P}>0.05$ ) because of a large variation in $\mathrm{N}$ content between $\mathrm{CWD}$ 
samples. Measurements of $\mathrm{N}$ isotope ratio in log samples of decay class IV and $\mathrm{V}$ indicated that $\delta^{15} \mathrm{~N}$ was $0.6 \%$ or a $\log$ at Site C, whereas it ranged from 4.2 to $14.8 \%$ o (mean $=8.6 \%$, $\mathrm{n}=10$ ) for logs at Sites $\mathrm{P}, \mathrm{A}$, and D (Fig. 7), suggesting that excreta-derived $\mathrm{N}$ can be incorporated into logs during decomposition and that some logs served as a reservoir of excreta-derived $\mathrm{N}$ on the forest floor.

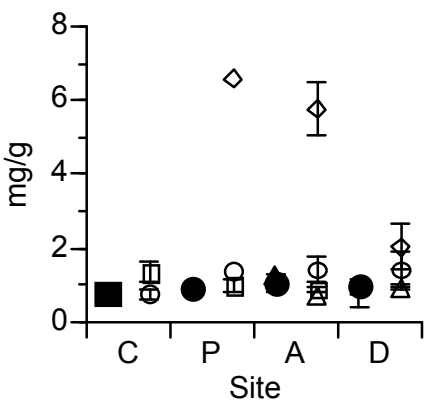

Fig. 14. Nitrogen content (mg/g) in coarse woody debris (CWD) of Chamaecyparis obtusa. snag, decay class I; $\ell$ snag, decay class II; « snag, decay class III; $\square \log$, decay class I; $\bigcirc \log$, decay class II; $\triangle \log$, decay class III; $\diamond \log$, decay class IV. Sites are as in Table 1 . Values indicate means \pm standard errors.

\section{Predicting the dynamics of dead plant tissues and excreta-derived nitrogen in colonized forest}

The previous sections demonstrated that the excess supply of $\mathrm{N}$ as excreta altered the patterns of decomposition of dead plant tissues due to the changes in the ecological (i.e., abundance, diversity, and species composition) and physiological (growth and ligninolytic activity) properties of saprobic fungi. The impact of birds on forest stands, however, is not limited to the supply of a large amount of excreta to the forest floor and the concomitant changes in biological properties in soils. Cormorants break needles and twigs for nesting material and frequently drop these on the forest floor. Such behavior results in a high volume of litterfall in the colonized forests (Section 1.3), which can lead to tree mortality and forest decline. The fallen needles and twigs abundantly supplied to the forest floor are expected to serve as large reservoirs of carbon and excreta-derived nutrients (Section 5). Moreover, the amount of litterfall and excreta deposition is expected to depend on the density of bird colonization, which varies in time and space (Fujiwara and Takayanagi, 2001).

In order to predict the impact of bird colonization on nutrient dynamics in soils, therefore, it is necessary to quantitatively relate the density of bird colonization to the amount of litterfall and to the amount of dead plant tissues and nutrients in the decomposing tissues. In this section, empirical linear models are constructed to describe the relationship between the number of cormorant nests (as an index of bird density) and (i) litterfall amount (denoted as Nest number-litterfall amount or NNLA model), (ii) amount of dead plant tissues remaining after a given period of decomposition (Nest number-residual mass or NNRM model), and (iii) amount of nutrients accumulated in dead plant tissues after a given period of decomposition (Nest number-residual nutrient or NNRN model). 


\subsection{Nest number-litterfall amount (NNLA) models}

Litterfall amount was measured for needles, twigs, and coarse woody debris (CWD) at the study sites and linearly related to the number of cormorant nests (Fig. 15). Here, CWD is sometimes equivalently referred to as stems when mentioning them as the living compartment of forest stands. The regression equations and coefficients of determination are:

$$
\begin{aligned}
& \text { Needle: } \mathrm{LF}_{\mathrm{NDL}}=0.0226 \times \mathrm{NE}+1.180\left(\mathrm{n}=6, \mathrm{R}^{2}=0.94, \mathrm{P}<0.01\right) \\
& \text { Twig: } \mathrm{LF}_{\mathrm{TWG}}=0.0104 \times \mathrm{NE}-0.164\left(\mathrm{n}=6, \mathrm{R}^{2}=0.74, \mathrm{P}<0.05\right) \\
& \text { CWD: } \mathrm{LF}_{\mathrm{CWD}}=0.0122 \times \mathrm{NE}-0.096\left(\mathrm{n}=4, \mathrm{R}^{2}=0.71, \mathrm{P}=0.16\right)
\end{aligned}
$$

where $\mathrm{LF}_{\mathrm{NDL}}, \mathrm{LF}_{\mathrm{TWG}}$, and $\mathrm{LF}_{\mathrm{CWD}}$ are litterfall amount ( $\mathrm{t} / \mathrm{ha} /$ year) of needles, twigs, and CWD, respectively, and NE is the number of cormorant nests (/ha/year). The coefficient of determination for CWD was not statistically significant at the $5 \%$ level because of the large variation of data and the low number of study sites examined.

These regression equations provide useful implications about the relationship between forest decline and nest number. According to previous literature, the biomass of needles, twigs, and stems in plantations of C. obtusa varied with location and stand age, ranging from 10 to 20 (13 on average, $n=22) t /$ ha for needles, 10 to 30 (15 on average) t/ha for twigs, and 50 to 200 (107 on average) t/ha for stems (Kawahara, 1974). Substituting the biomass data into equations 1, 2, and 3 yields the number of cormorant nests at which all biomass within a forest stand can be transformed into litterfall. Those are: 390 to 830 (520 on average) nests/ha/year for needles, 980 to 2900 (1460 on average) nests/ha/year for twigs, and 4100 to 16400 (8780 on average) nests / ha/year for stems.

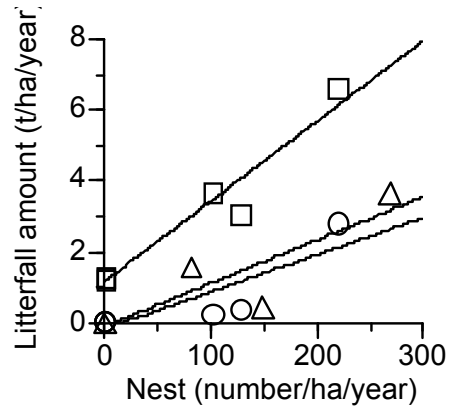

Fig. 15. Litterfall amount as related to the number of cormorant nests. $\square$ needles; $\bigcirc$ twigs; $\triangle$ coarse woody debris (CWD). Regression lines are for equations 1,2 , and 3, respectively. For needles and twigs, the litterfall amount and the nest number were measured simultaneously during the breeding season of cormorants in 1999 and 2000 at Sites T, P, and D (Fujiwara, 2001). For CWD, the litterfall amount was calculated by measuring diameters at breast height of trees that died (as standing-dead) during the periods of bird colonization starting from the years of colony establishment (1992 to 1997) to 2000 at Sites P, A, and D, as well as Site C (Fujiwara, 2001) and by converting these data to mass according to an allometric equation of Toda et al. (1991). The nest numbers at these sites during the periods of bird colonization were from Fujiwara (2001). 
This calculation suggests that all needles in a forest stand can fall when the annual number of nests reaches 400 to 800 , or when the cumulative number of nests over some years reaches those values. Because the needle is a photosynthetic organ and because C. obtusa is known to lack the ability to sprout (i.e. re-grow) after mechanical loss, 400 to 800 nests per ha will be a critical level at which the forest stand cannot maintain primary production and will start to decline. This prediction is in agreement with the observation at Site D, where the cormorants colonized intensively at least for 4 years, from 1992 to 1996, and then declined (Fujiwara, 2001). The number of cormorant nests in 1992 was 269 / ha at Site D (Fujiwara, 2001), which corresponds to a litterfall rate of needles of $7.3 \mathrm{t} / \mathrm{ha} /$ year according to equation 1. This estimated litterfall rate would be high enough to result in forest decline at Site D if similar colonization density of cormorants was maintained for 4 years.

\subsection{Nest number-residual mass (NNRM) model}

The exponential equation of Olson (1963) is used to describe the changes in remaining mass of needles, twigs, and CWD with respect to the period of decomposition. Data of the 2-year decomposition experiment at Site P (Fig. 11; Osono et al., 2006a) were used to estimate decomposition constants ( $k$, /year) for needles and twigs (Equations 4 and 5 ). Katsumata (2004) showed that more than $68 \%$ of CWD was present as snags in the study sites and that most of the snags persisted as standing-dead for more than 10 years but gradually shifted from decay class I to II (Fig. 13). Thus, a total of 32 snags, including those in decay class I at Sites $\mathrm{C}$ (no bird colonization; i.e., 0 year after colonization) and $\mathrm{P}$ ( 3 years) and in decay class I and II at Sites A (6 years) and D (10 years), were sampled to measure mass per volume. The mass per volume data of CWD were used to construct the pattern of changes in remaining mass per volume of snags and to estimate a decomposition constant for CWD by means of a chronosequence approach (Equation 6). The exponential equations are expressed as:

$$
\begin{aligned}
& \text { Needles: } \mathrm{MR}_{\mathrm{NDL}, t}=\mathrm{LF}_{\mathrm{NDL}} \times \exp ^{-0.27 t}\left(\mathrm{n}=7, \mathrm{R}^{2}=0.28\right) \\
& \text { Twigs: } \mathrm{MR}_{\mathrm{TWG}, t}=\mathrm{LF}_{\mathrm{TWG}} \times \exp ^{-0.03 t}\left(\mathrm{n}=7, \mathrm{R}^{2}=0.75\right) \\
& \text { CWD: } \mathrm{MR}_{\mathrm{CWD}, t}=\mathrm{LF}_{\mathrm{CWD}} \times \exp ^{-0.02 t}\left(\mathrm{n}=6, \mathrm{R}^{2}=0.75\right)
\end{aligned}
$$

where $\mathrm{MR}_{\mathrm{NDL}, t}, \mathrm{MR}_{\mathrm{TWG}, t}$, and $\mathrm{MR}_{\mathrm{CWD}, t}$ are the remaining mass ( $\left.\mathrm{t} / \mathrm{ha}\right)$ of needles, twigs, and CWD, respectively, at time $t$ and $t$ is the time in years. The decomposition constants $(k)$ are $0.27,0.03$, and 0.02 /year, respectively. The coefficient of determination for needles was low because of asymptotic pattern of changes in remaining mass over the study period (Fig. 11). Substituting equations 1-3 into exponential equations 4-6 yields the equations describing the relationship between the nest number and the remaining mass of needles, twigs, and CWD, respectively, at a given decomposition time $t$ (NNRM model):

$$
\begin{aligned}
& \text { Needles: } \mathrm{MR}_{\mathrm{NDL}, t}=(0.0226 \times \mathrm{NE}+1.180) \times \exp ^{-0.27 t} \\
& \text { Twigs: } \mathrm{MR}_{\mathrm{TWG}, t}=(0.0104 \times \mathrm{NE}-0.164) \times \exp ^{-0.03 t} \\
& \text { CWD: } \mathrm{MR}_{\mathrm{CWD}, t}=(0.0122 \times \mathrm{NE}-0.096) \times \exp ^{-0.02 t}
\end{aligned}
$$




\subsection{Nitrogen immobilization and Nest number-residual nutrient (NNRN) model}

Excreta-derived $\mathrm{N}$ was immobilized in decomposing needles and twigs (Section 5.2) and in CWD (Section 5.3). Osono et al. (2006a) estimated the potentials of these plant tissues to immobilize excreta-derived $\mathrm{N}$ (denoted here as the immobilization potential, which means the maximum amount of exogenous $\mathrm{N}$ immobilized per initial material) and the duration of this immobilization phase according to the method described in Mellilo and Aber (1984). Firstly, the linear relationships between the percent remaining mass of plant tissues and $\mathrm{N}$ content in the remaining materials were described as regression equations (Fig. 16):

$$
\begin{aligned}
& \text { Needles: } \mathrm{MR}_{\mathrm{NDL}} / \mathrm{LF}_{\mathrm{NDL}} \times 100=-20 \times \mathrm{NIT}_{\mathrm{NDL}}+120\left(\mathrm{n}=7, \mathrm{R}^{2}=0.76, \mathrm{P}<0.01\right) \\
& \text { Twigs: } \mathrm{MR}_{\mathrm{TWG}} / \mathrm{LF}_{\mathrm{TWG}} \times 100=-23 \times \mathrm{NIT}_{\mathrm{TIG}}+110\left(\mathrm{n}=7, \mathrm{R}^{2}=0.32, \mathrm{P}=0.18\right) \\
& \text { CWD: } \mathrm{MR}_{\mathrm{CWD}} / \mathrm{LF}_{\mathrm{CWD}} \times 100=-174 \times \mathrm{NIT}_{\mathrm{CWD}}+105\left(\mathrm{n}=6, \mathrm{R}^{2}=0.13, \mathrm{P}=0.48\right)
\end{aligned}
$$

where $\mathrm{NIT}_{\mathrm{NDL}}, \mathrm{NIT}_{\mathrm{TWG}}$, and $\mathrm{NIT}_{\mathrm{CWD}}$ are $\mathrm{N}$ content $(\%, \mathrm{w} / \mathrm{w})$ of needles, twigs, and CWD, respectively.

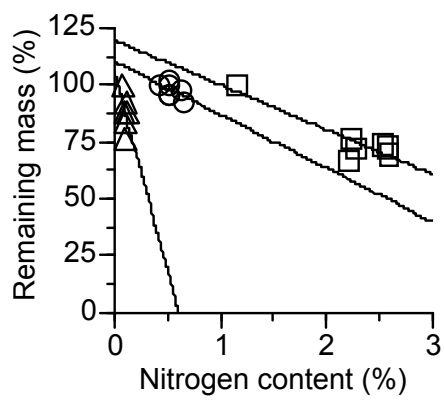

Fig. 16. Linear relationships between the percent remaining mass of decomposing plant tissues (\% of the original mass: $\left.\mathrm{MR}_{t} / \mathrm{LF} \times 100\right)$ and the $\mathrm{N}$ content $(\%, \mathrm{w} / \mathrm{w})$ in the remaining tissues for needles, twigs, and CWD. Symbols are as in Fig. 15.

Substituting the intercepts and slopes of equations 10-12 and the decomposition constants of equations 4-6 into the equations of Mellilo and Aber (1984), the immobilization potential was calculated to be $6.6,8.6$, and $0.8 \mathrm{mg} \mathrm{N} / \mathrm{g}$ initial material and the duration of the immobilization phase to be 1.6, 19.9, and 32.2 years for needles, twigs, and CWD, respectively.

Using these values, Osono et al. (2006a) estimated the $\mathrm{N}$ immobilization potential of litterfall to be 10.3 and $7.2 \mathrm{~kg} / \mathrm{ha} /$ month for needles and twigs, respectively. These values accounted for $4.1 \%$ and $3.0 \%$ of total $\mathrm{N}$ input as excreta during the breeding season at Site P (i.e., 240 $\mathrm{kg} / \mathrm{ha} /$ month; Kameda et al., 2006). This tentative calculation thus suggests that the increased litterfall at Site $\mathrm{P}$ due to breeding activity of the cormorants has a potential to immobilize only a total of $7 \%$ of total excreta-derived $\mathrm{N}$ deposited on the forest floor during 2 (needles) and 20 (twigs) years of decomposition. The major fate of excreta-derived $\mathrm{N}$ thus can be leaching into deeper soil layers (Hobara et al., 2005) and volatilization as ammonia gas into the atmosphere.

Finally, substituting equations 10-12 into equations 7-9 yields equations describing the relationship between the nest number and $\mathrm{N}$ mass $(\mathrm{kg} / \mathrm{ha})$ in the remaining needles, twigs, and CWD, respectively, at a given decomposition time $t$ (NNRN model): 
Needles:

$$
\mathrm{NIT}_{\mathrm{NDL}, t}=\left[(0.0226 \times \mathrm{NE}+1.180) \times \exp ^{-0.27 t}\right] \times\left[\left(100 \times \exp ^{-0.27 t}-120\right) /(-20)\right] \times 10
$$

Twigs:

$$
\mathrm{NIT}_{\mathrm{NDL}, t}=\left[(0.0104 \times \mathrm{NE}+0.164) \times \exp ^{-0.03 t}\right] \times\left[\left(100 \times \exp ^{-0.03 t}-110\right) /(-23)\right] \times 10
$$

CWD:

$$
\mathrm{NIT}_{\mathrm{NDL}, t}=\left[(0.0122 \times \mathrm{NE}+0.096) \times \exp ^{-0.02 t}\right] \times\left[\left(100 \times \exp ^{-0.02 t}-105\right) /(-174)\right] \times 10
$$

\subsection{Dynamics of dead plant tissues and excreta-derived nitrogen in colonized forest}

Using the empirical models in equations 7-9 and 13-15, long-term patterns of the remaining mass of dead plant tissues and in the $\mathrm{N}$ mass during decomposition were estimated for forest stands colonized by cormorants (Fig. 17). The models show the different roles of plant tissues as components of the forest floor and reservoirs of excreta-derived $\mathrm{N}$.

At the time of litterfall (i.e., 0 year), needles, twigs, and CWD account for approx. $50 \%, 25 \%$, and $25 \%$ of total litterfall, respectively (Fig. 17). However, needles almost disappear before 20 years of decomposition because the mass loss for them is much faster than that for twigs and CWD. After 20 years twigs and CWD constitute the dominant components of the detritus pool in the forest stand. Although not shown in Fig. 17, CWD becomes two times more important quantitatively than twigs at $\sim 60$ years of decomposition.
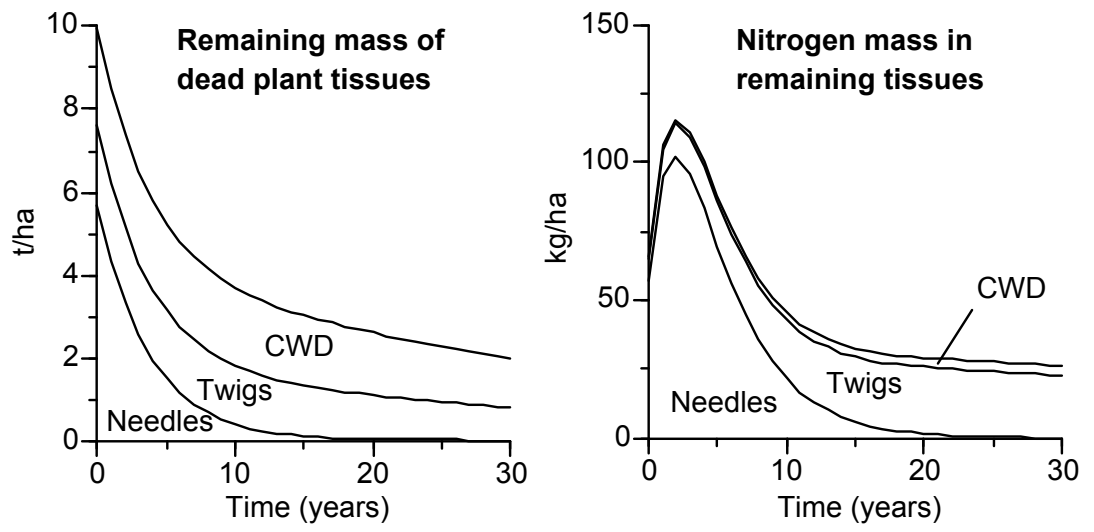

Fig. 17. Estimated long-term changes in the remaining mass of dead plant tissues and the nitrogen mass in the remaining tissues during decomposition in forest stand colonized by cormorants at 200 nests/ha, the mean value at Isaki Peninsula in 2000 (Fujiwara, 2001). The models start with litterfall in a single year, and the figures show decomposition for 30 years.

Needles account for $87 \%$ of $\mathrm{N}$ in dead plant tissues at the time of litterfall because the initial $\mathrm{N}$ contents are 3 and 15 times higher than in twigs and CWD, respectively (Fig. 17). During the first two years of decomposition, $\mathrm{N}$ mass in needles increased 1.8 times compared to that of the initial mass due to the net immobilization of excreta-derived $\mathrm{N}$ (Section 5.2). The $\mathrm{N}$ 
mass reached its maximum value at 3 years of decomposition but decreased thereafter due to the net release from needles. The $\mathrm{N}$ mass in needles becomes smaller exponentially, and it almost disappears before 20 years of decomposition. This suggests that needles serve as a temporary reservoir and then as a source of $\mathrm{N}$ thereafter up to 20 years of decomposition. In contrast, twigs immobilize $\mathrm{N}$ slowly for 20 years to become the dominant reservoir of $\mathrm{N}$ thereafter. The model predicts that CWD (snags) plays a negligible role in $\mathrm{N}$ retention. Note, however, that a part of CWD can be a reservoir of $\mathrm{N}$ when it falls down to become logs (Section 5.3), a process not incorporated in the model.

It should also be noted that some equations in the models have low coefficients of determination. This especially holds true for the litterfall amount of CWD (Eq. 3), the changes in remaining mass of needles (Eq. 4), and the dynamics of $\mathrm{N}$ in twigs and CWD (Eqs. 11 and 12). When the decomposition of needles is assumed to follow an asymptotic function, for example, needles become a more important, longer-term reservoir of dead plant tissues and $\mathrm{N}$ in the detritus pool. Obviously, longer-term studies of tree mortality and decomposition of needles, twigs, and CWD will be necessary to construct more accurate empirical models. Still, the present models provide useful insights into the effects of the density of cormorant colonization on the amount of litterfall and into the differential roles of dead plant tissues as reservoirs of carbon and excreta-derived $\mathrm{N}$.

\section{Conclusion}

The series of studies demonstrated that excess supply of excreta-derived $\mathrm{N}$ changed the community structure, nutrition, and substrate utilization of saprobic fungi, which by altering the decomposition processes led to carbon sequestration, accumulation of excretaderived $\mathrm{N}$, and thus a slow turnover of carbon and $\mathrm{N}$ in forest soils affected by the cormorant (Fig. 18). Most of the previous studies examined the effects of excess supply of nutrients on fungal communities, microbial activities, decomposition processes, or soil carbon accumulation separately, and the interactions and possible causal relationships between these biological and ecosystem processes have rarely been explored. This case study of cormorant-derived excreta deposition in conifer plantations at Isaki Peninsula thus can provide useful implications for the understanding of biological mechanisms underlying the $\mathrm{N}$-induced sequestration of soil carbon in forest ecosystems supplemented with excess nutrients.

The past century is the first time since the evolution of modern $\mathrm{N}$ cycle linked to microbial processes with robust natural feedbacks and controls that human activities may have produced the largest impact on global N cycle (Canfield et al., 2010). Disrupted N cycles due to excess supply of $\mathrm{N}$ of anthropogenic origin and the concomitant buildup of $\mathrm{N}$ and carbon sequestration in forest soils are one of major global issues because of its potential influence on the evolution of carbon dioxide and feedback to global warming (Nadelhoffer et al., 1999; de Vries et al., 2006). The present study highlights potential importance of fungi and their indispensable roles linking $\mathrm{N}$ deposition with carbon sequestration in soils. Future research directions include the dynamics of phosphorus (Conley et al., 2009), another major nutrient that is abundantly contained in excreta (Hobara et al., 2005), and which limits primary production more frequently than $\mathrm{N}$ and has different effects on soil processes and fungal activity. 


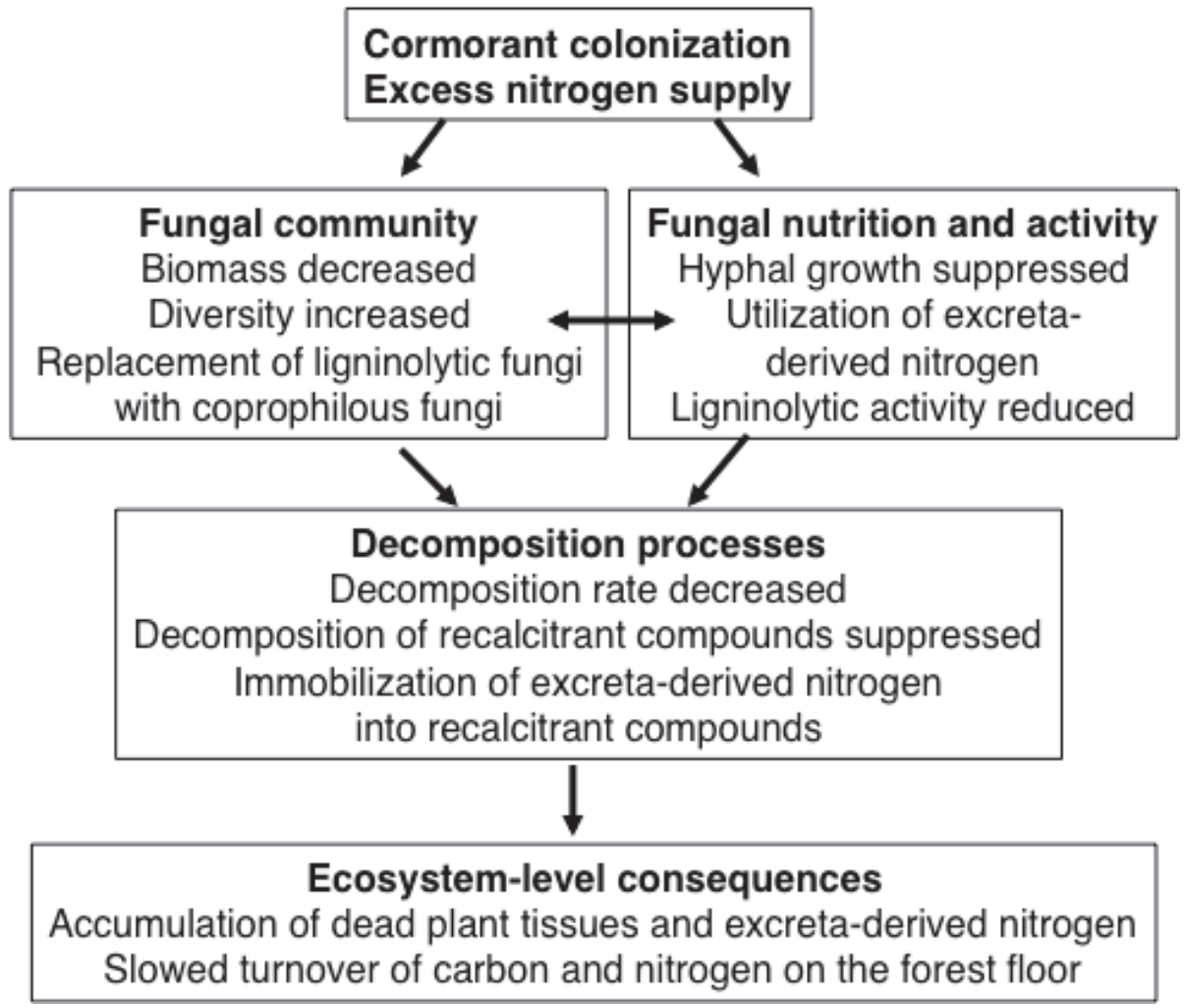

Fig. 18. Schematic diagram showing the possible effects of excess supply of excreta-derived nitrogen on fungal community and activity and decomposition processes and its ecosystem consequences.

\section{Acknowledgments}

I thank Drs. Kayoko Kameda, Satoru Hobara, Keisuke Koba, Akira Ishida, Yu Fukasawa, and Hiroshi Takeda, Mrs. Satomi Fujiwara, and Mr. Shingo Katsumata for collaborations in the research projects; Drs. Seiji Tokumasu and Susumu Iwamoto for helpful identification of fungi; and Dr. Elizabeth Nakajima for proofreading of the manuscript. Dr. Kayoko Kameda kindly provided original data of Fig. 1. This study was supported by Global COE Program A06 of Kyoto University.

\section{References}

Aber, J.; McDowell, W.; Nadelhoffer, K.; Magill, A.; Berntson, G.; Kamakea, M.; McNulty, S.; Currie, W.; Rustad, L.; Fernandez, I. (1998). Nitrogen saturation in temperate forest ecosystems, hypotheses revisited. Bioscience, 48, 921-934

Anderson, W.B.; Polis, G.A. (1999). Nutrient fluxes from water to land: seabirds affect plant nutrient status on Gulf of California islands. Oecologia, 118, 324-332 
Berg, B. (1986). Nutrient release from litter and humus in coniferous forest soils - a mini review. Scandinavian Journal of Forest Research, 1, 359-369

Berg, B. (1988). Dynamics of nitrogen $\left({ }^{15} \mathrm{~N}\right)$ in decomposing Scots pine (Pinus sylvestris) needle litter. Long-term decomposition in a Scots pine forest. VI. Canadian Journal of Botany, 66, 1539-1546

Berg, B.; Matzner, E. (1997). Effect of $\mathrm{N}$ deposition on decomposition of plant litter and soil organic matter in forest systems. Environmental Review, 5, 1-25

Berg, B.; McClaugherty, C. (2003). Plant Litter, Decomposition, Humus Formation, Carbon Sequestration. Springer Verlag, Berlin

Blackwood, C.B.; Waldrop, M.P.; Zak, D.R.; Sinsabaugh, R.L. (2007). Molecular analysis of fungal communities and laccase genes in decomposing litter reveals differences among forest types but no impact of nitrogen deposition. Environmental Microbiology, 9, 1306-1316

Canfield, D.E.; Glazer, A.N.; Falkowski, P.G. (2010). The evolution and future of Earth's nitrogen cycle. Science, 330, 192-196

Conley, D.J.; Paerl, H.W.; Howarth, R.W.; Boesch, D.F.; Seitzinger, S.P.; Havens, K.E.; Lancelot, C.; Likens, G.E. (2009). Controlling eutrophication: nitrogen and phosphorus. Science, 323, 1014-1015

De Vries, W.; Reinds, G.J.; Gundersen, P.; Sterba, H. (2006). The impact of nitrogen deposition on carbon sequestration in European forests and forest soils. Global Change Biology, 12, 1151-1173

Fenn, P.; Choi, S.; Kirk, T.K. (1981). Ligninolytic activity of Phanerochaete chrysosporium: physiology of suppression by $\mathrm{NH}_{4}{ }^{+}$and L-glutamate. Archives in Microbiology, 130, 66-71

Fog, K. (1988). The effect of added nitrogen on the rate of decomposition of organic matter. Biological Review, 63, 433-462

Fujiwara, S. (2001). Forest decline in cormorant colonies. Master thesis, Kyoto University (in Japanese)

Fujiwara, S.; Takayanagi, A. (2001). The influence of the common cormorant (Phalacrocorax carbo Kuroda) on forest decline. Applied Forest Science, 10, 85-90 (in Japanese with English abstract)

Fukasawa, Y.; Osono, T.; Takeda, H. (2009). Effects of attack of saprobic fungi on twig litter decomposition by endophytic fungi. Ecological Research, 24, 1067-1073

Harmon, M.E.; Franklin, J.F.; Swanson, F.J.; Sollins, P.; Gregory, S.V.; Lattin, J.D.; Anderson, N.H.; Cline, S.P.; Aumen, N.G.; Sedell, J.R.; Lienkaemper, G.W.; Cromack, Jr., K.; Cummins, K.W. (1986). Ecology of coarse woody debris in temperate ecosystems. Advances in Ecological Research, 15, 133-302

Hassett, J.E.; Zak, D.R.; Blackwood, C.B.; Pregitzer, K.S. (2009). Are basidiomycete laccase gene abundance and composition related to reduced ligninolytic activity under elevated atmospheric $\mathrm{NO}_{3}{ }^{-}$deposition in a northern hardwood forest? Microbial Ecology, 57, 728-739

Hobara, S.; Osono, T.; Koba, K.; Tokuchi, N.; Fujiwara, S.; Kameda, K. (2001). Forest floor quality and $\mathrm{N}$ transformations in a temperate forest, affected by avian-derived $\mathrm{N}$ deposition. Water, Air, and Soil Pollution, 130, 679-684 
Hobara, S.; Koba, K.; Osono, T.; Tokuchi, N.; Ishida, A.; Kameda, K. (2005). Nitrogen and phosphorus enrichment and balance in forests colonized by cormorants: implications of the influence of soil adsorption. Plant and Soil, 268, 89-101

Ishida, A. (1996a). Changes in soil properties in the colonies of the common cormorant, Phalacrocorax carbo. Journal of Forest Research, 1, 31-35

Ishida, A. (1996b). Effects of the common cormorant, Phalacrocorax carbo, on evergreen forests in two nest sites at Lake Biwa, Japan. Ecological Research, 11, 193-200

Ishida, A.; Narusue, M.; Kameda, K. (2003). Management of Great Cormorant Phalacrocorax carbo hanedae colonies in Japan. Vogelwelt, 124, 331-337

Johnsgard, P.A. (1993). Cormorants, Darters, and Pelicans of the World. Smithosonian Institution Press, London

Kameda, K.; Koba, K.; Yoshimizu, C.; Fujiwara, S.; Hobara, S.; Koyama, L.; Tokuchi, N.; Takayanagi, A. (2000). Nutrient flux from aquatic to terrestrial ecosystem mediated by the Great Cormorant. Sylvia, 36, 54-55

Kameda, K.; Ishida, A.; Narusue, M. (2003). Population increase of the Great Cormorant Phalacrocorax carbo hanedae in Japan: conflicts with fisheries and trees and future perspectives. Vogelwelt, 124, 27-33

Kameda, K.; Koba, K.; Hobara, S.; Osono, T.; Terai, M. (2006). Mechanism of long-term effects of cormorant-derived nitrogen in a lakeside forest. Hydrobiologia, 567, 69-86

Katsumata, S. (2004). Biomass and nutrient contents of coarse woody debris in forest stands colonized by the cormorants. Bachelor thesis, Kyoto University (in Japanese)

Kawahara, T. (1974). Stock and circulation of nutrients within ecosystem, In: Chamaecyparis obsuta forests: its ecology and natural regeneration, T. Shidei, (Ed.), 131-209, Chikyusha, Japan (in Japanese)

Keyser, P.; Kirk, T.K.; Zeikus, J.G. (1978). Ligninolytic enzyme system of Phanerochaete chrysosporium: synthesized in the absence of lignin in responses to nitrogen starvation. Journal of Bacteriology, 135, 790-797

Kohzu, A.; Yoshioka, T.; Ando, T.; Takahashi, M.; Koba, K.; Wada, E. (1999). Natural ${ }^{13} \mathrm{C}$ and ${ }^{15} \mathrm{~N}$ abundance of field-collected fungi and their ecological implications. New Phytologist, 144, 323-330

Koide, K.; Osono, T. (2003). Chemical composition and mycobiota of bleached portion of Camellia japonica leaf litter at two stands with different nitrogen status. Japanese Journal of Forestry Society, 85, 359-363 (in Japanese with English abstract)

Mellilo, J.M.; Aber, J.D. (1984). Nutrient immobilization in decaying litter: an example of carbon-nutrient interactions, In: Trends in Ecological Research for the 1980s, J.H. Cooley, F.B. Gooley (Eds.), 193-215, Plenum Press, New York

Mizutani, H.; Wada, E. (1988). Nitrogen and carbon isotope ratios in seabird rookeries and their ecological implications. Ecology, 69, 340-349

Nadelhoffer, K.J.; Emmett, B.A.; Gundersen, P.; Kjønaas, O.J.; Koopmans, C.J.; Schleppi, P.; Tietema, A.; Wright, R.F. (1999). Nitrogen deposition makes a minor contribution to carbon sequestration in temperate forests. Nature, 398, 145-148

Nagasaka, A.; Nagasaka, Y.; Ito, K.; Mano, T.; Yamanaka, M.; Katayama, A.; Sato, Y.; Grankin, A.L.; Zdorikov, A.I.; Boronov, G.A. (2006). Contributions of salmonderived nitrogen to riparian vegetation in the northwest Pacific region. Journal of Forest Research, 11, 377-382 
Ninomiya, A.; Antunes, M.F.R.; Schoenlein-Crusius, I.H. (1993). Fungi from soil affected by birds in the Parque Estadual Das Fontes Do Ipiranga, São Paulo State, Brazil. Revista de Microbiologia, 24, 49-53

Olson, J. (1963). Energy storage and the balance of produces and decomposers in ecological systems. Ecology, 44, 322-331

Osono, T. (2007). Ecology of ligninolytic fungi associated with leaf litter decomposition. Ecolgical Research, 22, 955-974

Osono, T.; Takeda, H. (2001). Effects of organic chemical quality and mineral nitrogen addition on lignin and holocellulose decomposition of beech leaf litter by Xylaria sp. European Journal of Soil Biology, 37, 17-23

Osono, T.; Hobara, S.; Fujiwara, S.; Koba, K.; Kameda, K. (2002). Abundance, diversity, and species composition of fungal communities in a temperate forest affected by excreta of the Great Cormorant Phalacrocorax carbo. Soil Biology \& Biochemistry, 34, 15371547

Osono, T.; Takeda, H. (2004). Accumulation and release of nitrogen and phosphorus in relation to lignin decomposition in leaf litter of 14 tree species. Ecological Research, $19,593-602$

Osono, T.; Hobara, S.; Koba, K.; Kameda, K.; Takeda, H. (2006a). Immobilization of avian excreta-derived nutrients and reduced lignin decomposition in needle and twig litter in a temperate coniferous forest. Soil Biology \& Biochemistry, 38, 517-525

Osono, T.; Hobara, S.; Koba, K.; Kameda, K. (2006b). Reduction of fungal growth and lignin decomposition in needle litter by avian excreta. Soil Biology E Biochemistry, 38, 16231630

Preston, C.M.; Trofymow, J.A.; Sayer, B.G.; Nie, J. (1997). ${ }^{13 C}$ nuclear magnetic resonance spectroscopy with cross-polarization and magic-angle spinning investigation of the proximate-analysis fractions used to assess litter quality in decomposition studies. Canadian Journal of Botany, 75, 1601-1613

Schoenlein-Crusius, I.H.; Trufem, S.F.B.; Malatinsky, S.M.M.; Ninomiya, A.; Antunes, M.F.R. (1996). Mucorales (Zygomycotina) from soil affected by excrement of birds in the Parque Estadual das Fontes do Ipiranga, São Paulo, Brazil. Revista Brasileira de Botanica, 19, 7-10

Sinsabaugh, R.L. (2010) Phenol oxidase, peroxidase and organic matter dynamics of soil. Soil Biology \& Biochemistry, 42, 391-404

Söderström, B.; Bååth, E.; Lundgren, B. (1983). Decrease in soil microbial activity and biomass owing to nitrogen amendments. Canadian Journal of Microbiology 29, 15001506

Sollins, P. (1982). Input and decay of coarse woody debris in coniferous stands in western Oregon and Washington. Canadian Journal of Forest Research, 12, 18-28

Toda, H.; Haibara, K.; Arai, M. (1991) Nutrient circulation in a small watershed under an established sugi (Cryptomeria japonica) and hinoki (Chamaecyparis obtusa) stand. Bulletin of University Forest of Tokyo University of Agriculture and Technology, 28, 1-22 (in Japanese with English abstract)

Trudell, S.A.; Rygiewicz, P.T.; Edmonds, R.L. (2004). Patterns of nitrogen and carbon stable isotope ratios in macrofungi, plants and soils in two old-growth conifer forests. New Phytologist, 164, 317-335 
Wainright, S.C.; Haney, J.C.; Kerr, C.; Golovkin, A.N.; Flint, M.V. (1998). Utilization of nitrogen derived from seabird guano by terrestrial and marine plants at St. Paul, Pribilof Islands, Bering Sea, Alaska. Marine Biology, 131, 63-71

Waldrop, M.P.; Zak, D.R. (2006). Response of oxidative enzyme activities to nitrogen deposition affects soil concentrations of dissolved organic carbon. Ecosystems, 9, 921-933

Wilkinson, C.E.; Hocking, M.D.; Reimchen, T.E. (2005). Uptake of salmon-derived nitrogen by mosses and liverworts in coastal British Columbia. Oikos, 108, 85-98

Zak, D.R.; Holmes, W.E.; Burton, A.J.; Pregitzer, K.S.; Talhelm, A.F. (2008). Simulated atmospheric $\mathrm{NO}_{3}{ }^{-}$deposition increases soil organic matter by slowing decomposition. Ecological Applications, 18, 2016-2027 


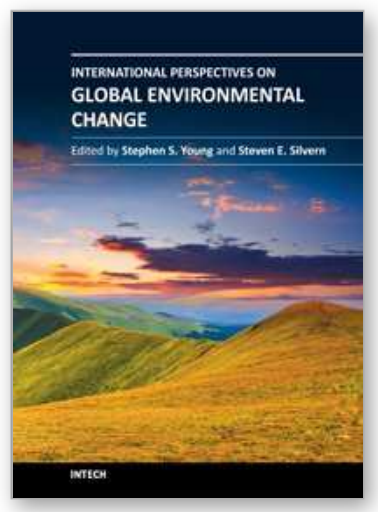

\author{
International Perspectives on Global Environmental Change \\ Edited by Dr. Stephen Young
}

ISBN 978-953-307-815-1

Hard cover, 488 pages

Publisher InTech

Published online 03, February, 2012

Published in print edition February, 2012

Environmental change is increasingly considered a critical topic for researchers across multiple disciplines, as well as policy makers throughout the world. Mounting evidence shows that environments in every part of the globe are undergoing tremendous human-induced change. Population growth, urbanization and the expansion of the global economy are putting increasing pressure on ecosystems around the planet. To understand the causes and consequences of environmental change, the contributors to this book employ spatial and nonspatial data, diverse theoretical perspectives and cutting edge research tools such as GIS, remote sensing and other relevant technologies. International Perspectives on Global Environmental Change brings together research from around the world to explore the complexities of contemporary, and historical environmental change. As an InTech open source publication current and cutting edge research methodologies and research results are quickly published for the academic policy-making communities. Dimensions of environmental change explored in this volume include: Climate change Historical environmental change Biological responses to environmental change Land use and land cover change Policy and management for environmental change

\title{
How to reference
}

In order to correctly reference this scholarly work, feel free to copy and paste the following:

Takashi Osono (2012). Excess Supply of Nutrients, Fungal Community, and Plant Litter Decomposition: A Case Study of Avian-Derived Excreta Deposition in Conifer Plantations, International Perspectives on Global Environmental Change, Dr. Stephen Young (Ed.), ISBN: 978-953-307-815-1, InTech, Available from: http://www.intechopen.com/books/international-perspectives-on-global-environmental-change/excess-supplyof-nutrients-fungal-community-and-plant-litter-decomposition-a-case-study-of-avian-der

\section{INTECH}

open science / open minds

\author{
InTech Europe \\ University Campus STeP Ri \\ Slavka Krautzeka 83/A \\ 51000 Rijeka, Croatia \\ Phone: +385 (51) 770447 \\ Fax: +385 (51) 686166 \\ www.intechopen.com
}

\author{
InTech China \\ Unit 405, Office Block, Hotel Equatorial Shanghai \\ No.65, Yan An Road (West), Shanghai, 200040, China \\ 中国上海市延安西路65号上海国际贵都大饭店办公楼405单元 \\ Phone: +86-21-62489820 \\ Fax: +86-21-62489821
}


(C) 2012 The Author(s). Licensee IntechOpen. This is an open access article distributed under the terms of the Creative Commons Attribution 3.0 License, which permits unrestricted use, distribution, and reproduction in any medium, provided the original work is properly cited. 